\title{
Composition of Trace Metals in Dust Samples Collected from Selected High Schools in Pretoria, South Africa
}

\author{
J. O. Olowoyo, L. L. Mugivhisa, and Z. G. Magoloi \\ Department of Biology, Sefako Makgatho Health Sciences University, P.O. Box 139, Medunsa, Pretoria 0204, South Africa \\ Correspondence should be addressed to J. O. Olowoyo; woleolowoyo@yahoo.com
}

Received 1 September 2016; Revised 18 October 2016; Accepted 24 October 2016

Academic Editor: Marco Trevisan

Copyright (C) 2016 J. O. Olowoyo et al. This is an open access article distributed under the Creative Commons Attribution License, which permits unrestricted use, distribution, and reproduction in any medium, provided the original work is properly cited.

\begin{abstract}
Potential health risks associated with trace metal pollution have necessitated the importance of monitoring their levels in the environment. The present study investigated the concentrations and compositions of trace metals in dust samples collected from classrooms and playing ground from the selected high schools In Pretoria. Schools were selected from Pretoria based on factors such as proximity to high traffic ways, industrial areas, and residential areas. Thirty-two dust samples were collected from inside and outside the classrooms, where learners often stay during recess period. The dust samples were analysed for trace metal concentrations using Inductively Coupled Plasma-Mass Spectrometry (ICP-MS). The composition of the elements showed that the concentrations of $\mathrm{Zn}$ were more than all other elements except from one of the schools. There were significant differences in the concentrations of trace metals from the schools $(p<0.05)$. Regular cleaning, proximity to busy road, and well maintained gardens seem to have positive effects on the concentrations of trace metals recorded from the classrooms dust. The result further revealed a positive correlation for elements such as $\mathrm{Pb}, \mathrm{Cu}, \mathrm{Zn}, \mathrm{Mn}$, and $\mathrm{Sb}$, indicating that the dust might have a common source.
\end{abstract}

\section{Introduction}

Dust from the urban area has been reported to contain toxic organic and inorganic pollutants such as trace metals [1]. The presence of trace metals in urban dust may be a result of various mobile and stationary sources such as vehicle exhaust, sinking particles in air, house dust, soil dust, and aerosols that are carried by air and water [2]. Therefore, during dust transportation, pollutants such as trace metals may form part of the street dust as they are blown by wind [3, 4]. Dust-laden air may deposit trace metals on food, drink, and surfaces of indoor appliances and this may often result in carcinogenic or noncarcinogenic health risk to residents, especially children [5]. Ingestion of dusts appeared to be the main route of exposure to dust particles and consequently pose a higher health risk [6]. Inhalation and dermal uptake are the other pathways in which trace metals can enter into the human systems [7].

Levels of trace metals in the environment are of major concern due to their nonbiodegradable and toxic nature especially if accumulated at levels higher than those required in the body [8]. Accumulation of trace metals in human tissues and other organs of the body can have adverse effect on the central nervous system acting as cofactors, stimulants, and promoters of other diseases and may likely result in trace metal related diseases later in life [9]. Pupils from high schools can easily ingest dust from classrooms or playing grounds and may adversely affect their retention ability [10].

Several studies have pointed to factors such as small and overcrowded classrooms, location of industries, vibrant outdoor activities of students during school recess, endemic dusty environment, and infrequent washing of hands as factors that may increase the likelihood of hand contamination and hand-to-mouth transfer of some trace elements among school children [11].

Previous studies carried out in South Africa have demonstrated high levels of trace metals in urban soils of South Africa introduced by emissions from vehicles and/or industries [12-14]. The study conducted in Johannesburg, South Africa, noted that it is necessary for policy makers to carry out a risk assessment of the levels of trace metals in South African schools that are located in close proximity to potential sources of pollution such as mining and industries 
and traffic congested areas [14]. The study reported on high levels of trace metals from soils used to plant vegetables and vegetables harvested from some school gardens practicing feeding schemes to alleviate hunger among learners. It needs to be emphasized that the socioecological conditions in many urban schools in South Africa may increase the risk of dust exposure as some of the factors listed above are predominant features of some of these schools. Despite the aforementioned factors, some schools environment in urban areas has not received the attention and public concern that it deserves in terms of managing and reducing the level of risk that may arise as a result of pollutants from dust. Few countries currently have guidelines and procedures for dealing with this risk associated with pollution from either industries or vehicular emissions [15]. The present study investigated the concentration and composition of trace metals in dust collected from some selected schools classrooms and playing grounds. The study further examined some possible sources of various forms of pollution within the selected schools.

\section{Methodology}

An approval to carry out the research was obtained from the Gauteng Department of Education in South Africa after approval by the relevant research committee at Sefako Makgatho Health Sciences University, Pretoria, South Africa.

Schools were selected from Pretoria based on factors such as proximity to high traffic ways, industrial areas, and residential areas. The sampling was done during the month of September. Samples were collected from eight schools, 2 separate samples from the playing ground each containing four different samples and 2 samples from two different classrooms each containing four samples, making a total of four samples from each of the schools, with a total of 32 samples. The samples from the classrooms were collected from window sills, bookshelves, and wall corners in the classrooms. Classrooms facing the direction of wind blow and where windows were often opened were selected for classrooms dust samples collection. The dust samples were collected using a clean plastic brush and a tray, labelled and stored in separate plastic bags for each of the samples. The weight of the dust samples collected from each classroom ranged between $110 \mathrm{~g}$ and $132 \mathrm{~g}$. The dust samples from the classrooms were composite samples representing the classroom dust labelled as CD1 and CD2, respectively. Soil dusts were also collected from two different areas (playing ground (SD1) and assembling area (SD2)), each having four sampling stations, and were thoroughly mixed as a representative sample. Larger grits and dirt were removed from the dried dust samples and further sieved with a sieve size of $<2 \mathrm{~mm}$ before being homogenized with mortar and pestle. The samples were air-dried in the laboratory for $24 \mathrm{~h}$ (care was taken to prevent cross contamination from laboratory dusts by first cleaning the laboratory and closing all the windows during the air drying period). The collected samples were kept in sealed polythene vials before analysis.

For the analysis of trace metals, the dust samples were acid-digested using $2 \mathrm{~mL} \mathrm{HCl}, 2 \mathrm{~mL} \mathrm{H}_{2} \mathrm{O}_{2}$, and $5 \mathrm{~mL} \mathrm{HNO}_{3}$.
The resulting solution was made up to volume with deionized water and analysed for trace metal content using ICP-MS. For the purpose of quality assurance, certified reference materials (CRM) purchased from NIST (PS-1 COOMET COD 310b) was also digested in the same way and analysed for trace metals contents. Precision for the CRM was around 5-7\% for most of the elements determined, and the overall recovery rate ranged from 92 to $105 \%$. Analysis of the sample was also carried out in triplicate so as to ensure the accuracy of the results obtained and mean values with standard deviation were used as the final results.

The description and location of the schools used for this study were as follows.

School $A$ is close to a very busy road. There are no pavements in most part of the school which may facilitate dust transportation into most of the classrooms. Cleaning is carried out once in a week by the learners. School B has dusty environment and there is no pavement or garden in the school and it is very close to a busy road. Cleaning is carried out once in a week by the learners. School $C$ is well paved with grasses and beautiful garden. There is air conditioning system in the classrooms used for cooling during summer and heating the classrooms during winter; hence it may not be necessary to open the window. The least grams of classroom dusts were collected from this school. Cleaning is carried out daily by the learners and supervised by the educators. School $D$ is close to a very busy road. Windows are always open and this results in a dusty classroom. Cleaning is carried out by learners every second day. School $E$ is not far away from a busy road; cleaners and students assist in cleaning the classrooms. School F is located in a residential area; schools are properly cleaned everyday by cleaners with open field with grasses and some pavements around the classrooms. School $G$ is close to a very busy road. The school is well paved; cleaners are employed and carried out cleaning daily. School $H$ has classrooms that are close to a very busy road. Cleaning is carried out once in a week on Fridays by the learners and is not usually supervised by the educators. Highest amount of dust from classrooms in this study was collected from this school.

\section{Statistical Analysis}

Statistical analysis of the data was carried out using Statistical Package for Social Sciences (SPSS) version 23.0. One-way analysis of variance (ANOVA) was used to test significant differences among the mean concentrations of the heavy metals in the samples collected from the different schools.

\section{Results and Discussion}

The composition and nature of the elements in dust collected from the selected high schools are presented in Figures 1-8. With the exception of dust from School B, Zn accounted for the highest percentage of all the elements present in the dust soil samples. $Z n$ value from all the dust samples ranged from $41.1 \pm 0.31 \mu \mathrm{g} / \mathrm{g}$ to $290.3 \pm 3.05 \mu \mathrm{g} / \mathrm{g}$ and from $147.1 \pm 1.06 \mu \mathrm{g} / \mathrm{g}$ to $669.3 \pm 2.88 \mu \mathrm{g} / \mathrm{g}$ from classroom dust and soil dusts, 


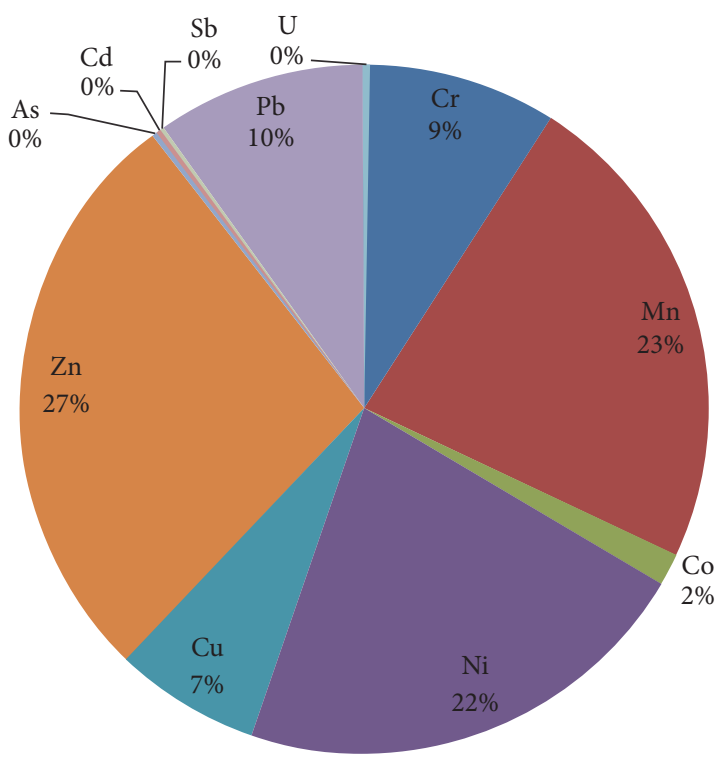

FIGURE 1: Distribution of trace metals in dust samples collected from School A.

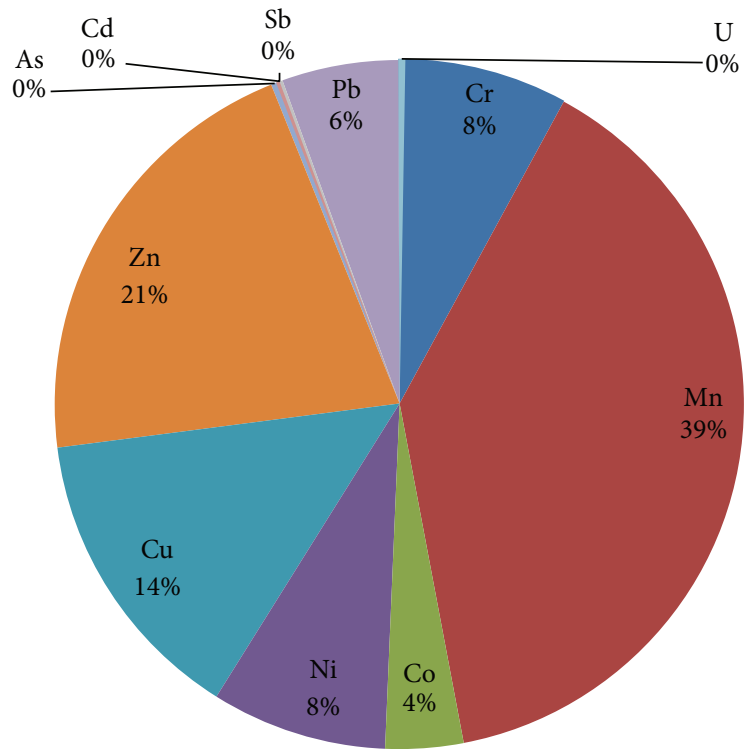

FIGURE 2: Distribution of trace metals in dust samples collected from School B.

respectively (Tables 1 and 2). The highest concentrations for $\mathrm{Zn}$ from both the soil and classrooms dust samples were recorded from School $\mathrm{H}$. The relevant standard value for this metal in South African soils is $200 \mu \mathrm{g} / \mathrm{g}$. The dominant nature of $\mathrm{Zn}$ in this study was similar to those reported from dust samples collected from office carpets and air conditioning systems from a university not far away from some of the schools [16]. Sources of $\mathrm{Zn}$ in the environment may be linked to wear and tear of tyres, lubricating oils and corrosion of galvanized vehicular parts. It could then be suggested that

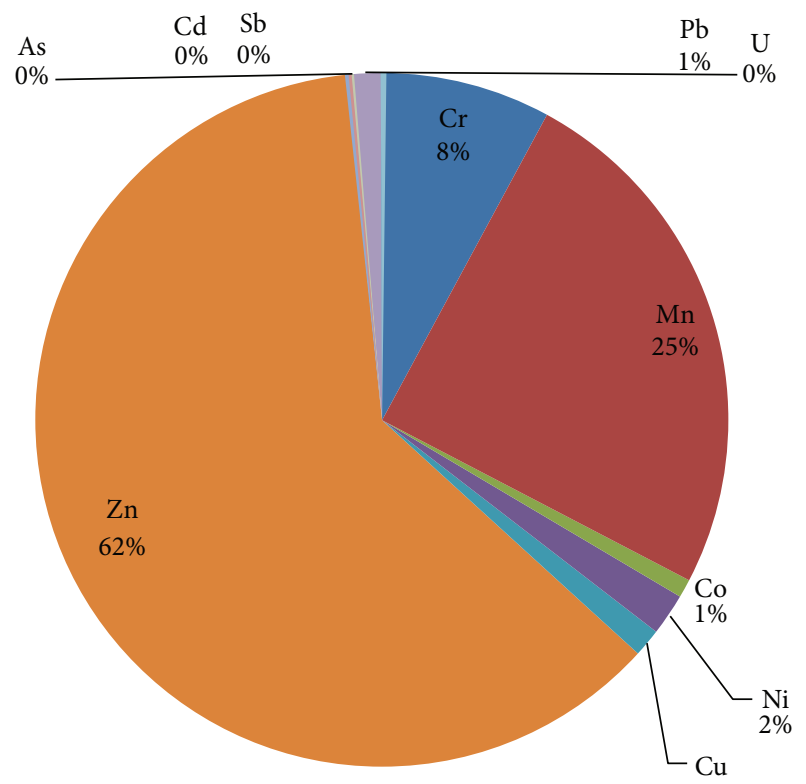

$1 \%$

FIgURE 3: Distribution of trace metals in dust samples collected from School C.

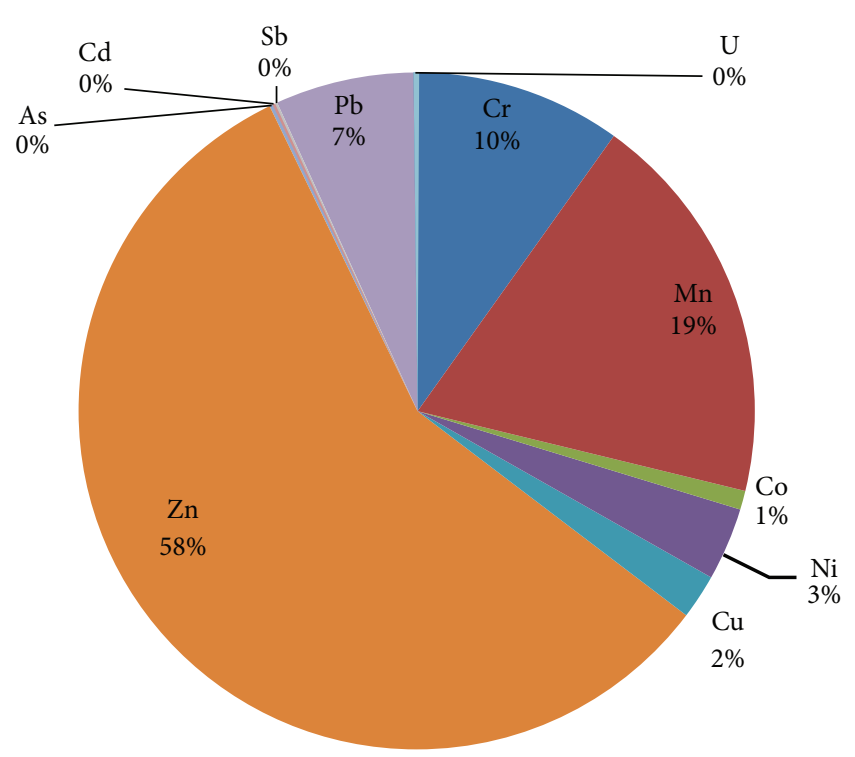

FIGURE 4: Distribution of trace metals in dust samples collected from School D.

the primary source of $\mathrm{Zn}$ from this present study might have come from various vehicular activities. Studies conducted in Spain showed that $\mathrm{Zn}$ and other elements such as $\mathrm{Cu}$ and $\mathrm{Sb}$ were more concentrated in areas associated with breaking activities [17]. Movement of students around these areas may also increase the concentration of $\mathrm{Zn}$ in classroom dusts as noted in this study. 


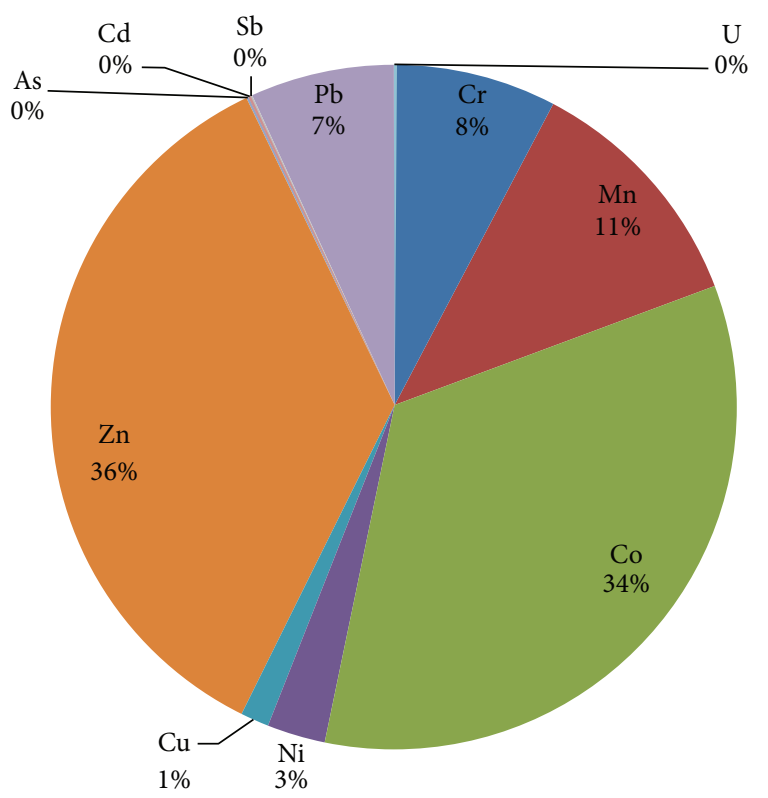

FIGURE 5: Distribution of trace metals in dust samples collected from School E.

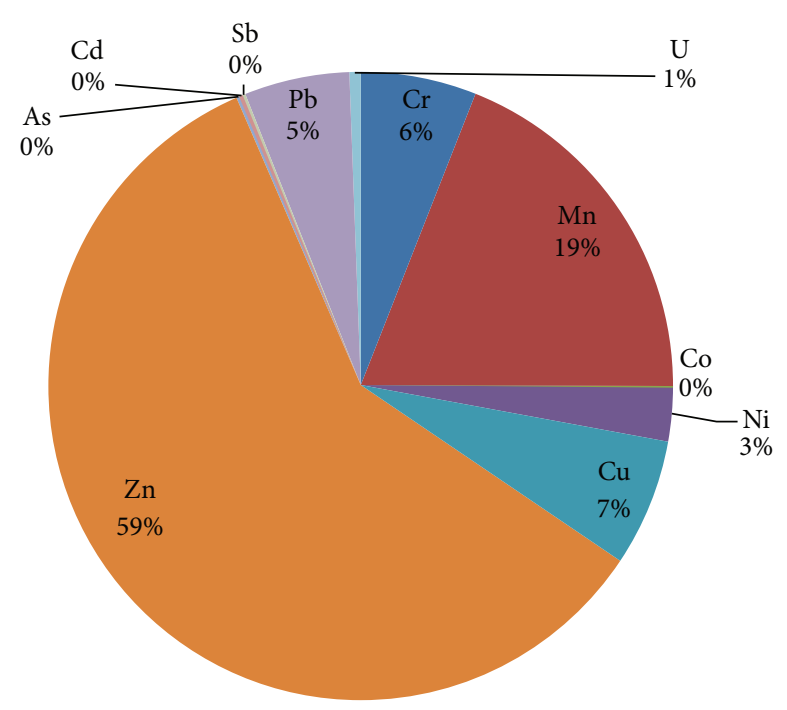

FIGURE 6: Distribution of trace metals in dust samples collected from School F.

The result also showed that concentrations of $\mathrm{Pb}$ from all the schools from both the soil and classroom dusts ranged from $7.37 \pm 0.02 \mu \mathrm{g} / \mathrm{g}$ to $304.6 \pm 11.8 \mu \mathrm{g} / \mathrm{g}$ (Tables 1 and 2 ). The highest mean concentration for $\mathrm{Pb}$ was recorded from soil dust (SD AII) from School A followed by classroom dust (CD H1) from School H $(251.7 \pm 5.29 \mu \mathrm{g} / \mathrm{g})$ (Tables 1 and 2 ). The values recorded for $\mathrm{Pb}$ in some of the classroom dust samples (CD) and soil dust (SD) were 12-15 times higher than the estimated natural lead concentration of $5-25 \mu \mathrm{g} / \mathrm{g}$. It should be noted that the concentrations of $\mathrm{Pb}$ from some of the classrooms dusts in this study were higher than the

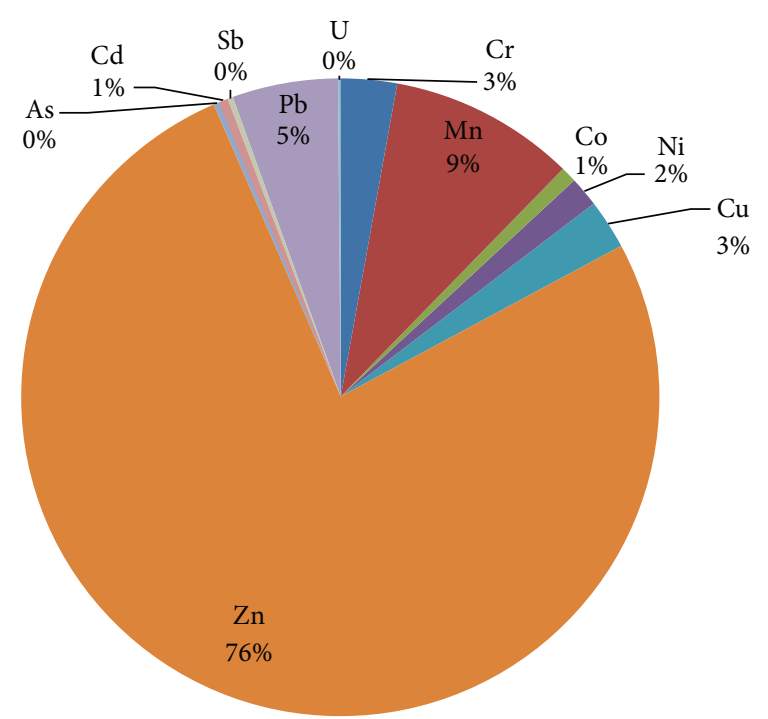

FIGURE 7: Distribution of trace metals in dust samples collected from School G.

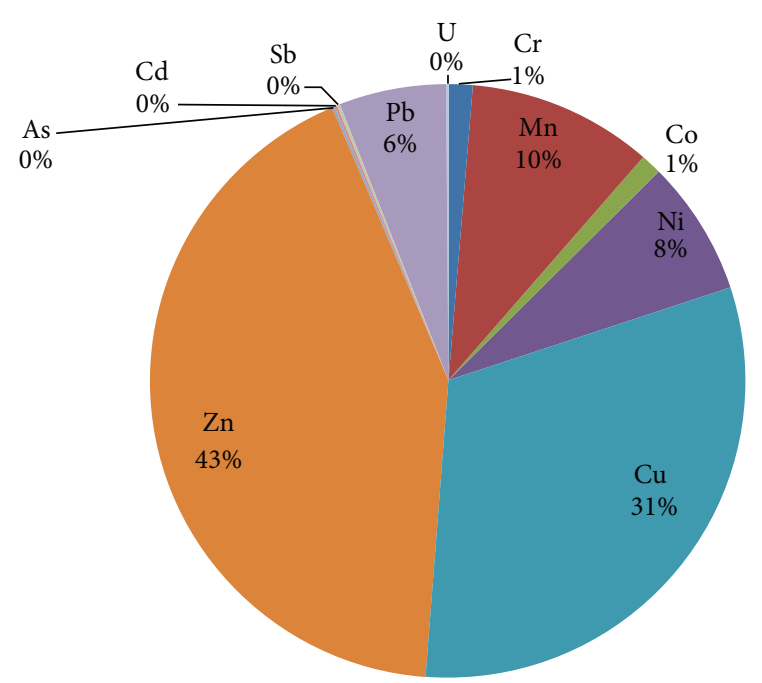

FIGURE 8: Distribution of trace metals in dust samples collected from School H.

background value of $100 \mu \mathrm{g} / \mathrm{g}$ documented for South African soils [18]. The significant differences noted in the concentrations of $\mathrm{Pb}$ from all the schools $(p<0.05)$ might have also suggested the impact of various anthropogenic inputs such as vehicular emissions and the impact of wind on the release and availability of this trace metal into the environment. In some of the schools, there were no significant differences in the concentrations of $\mathrm{Pb}$ recorded from classroom dusts and the soil dust $(p>0.05)$. This might be due to the influence of wind direction and movement of students carrying along attached dust particles in their shoes and clothes which may cause the dust particles to settle more in some of the classrooms [19]. Cleaning frequency and efficiency have been reported to possibly affect the concentration of metals in 


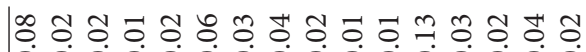

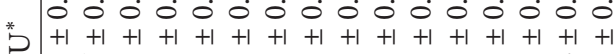

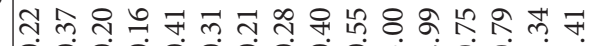

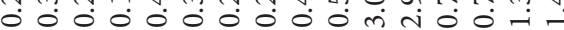

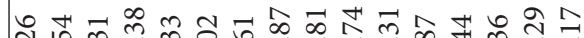

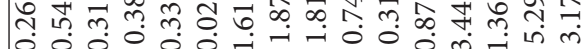
$0+1+1+1+1+1+1+1+1+1+1+1+1+1+1+1+1$

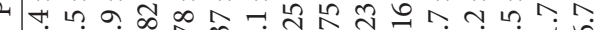

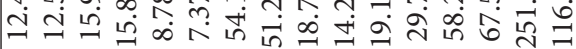

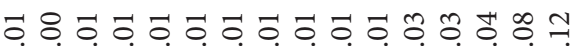

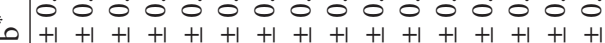

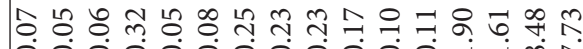

훙 ㅎำ

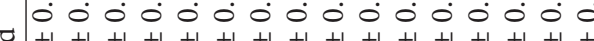

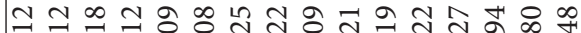

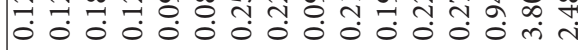

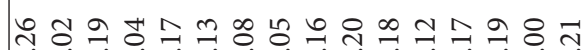
0.0000000000000000 $201+1+1+1+1+1+1+1+1+1+1+1+1+1+1+1$

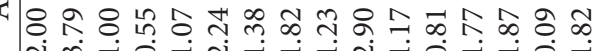

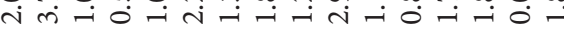

กิ

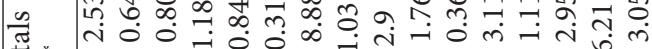

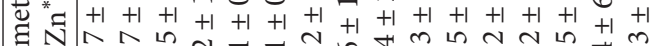

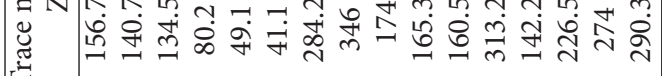

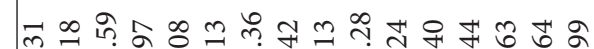
*

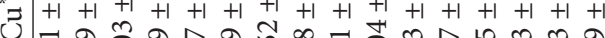

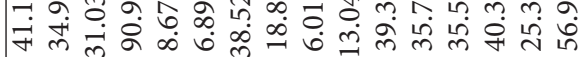

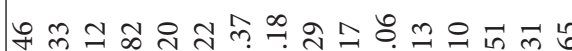

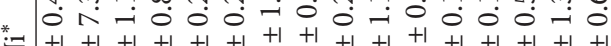

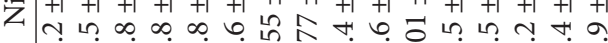
约它

โส ช

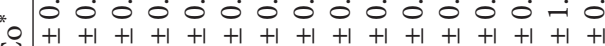

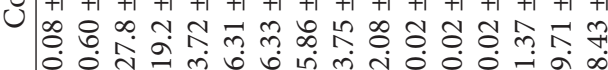
ก 0 ㅇำ

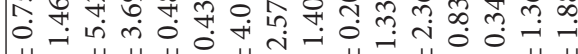

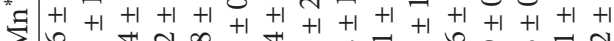

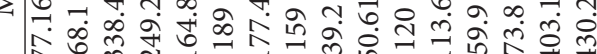

के

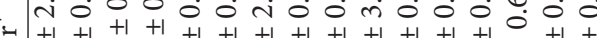

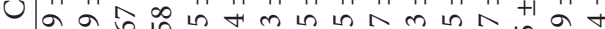

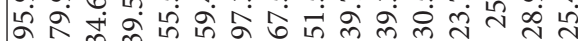

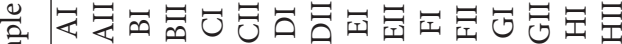

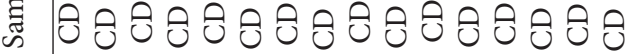

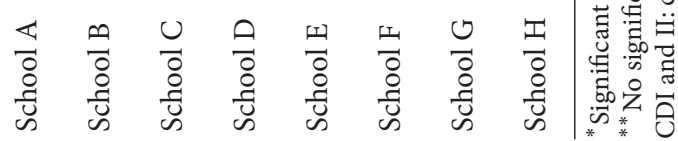




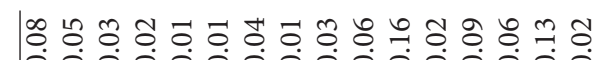

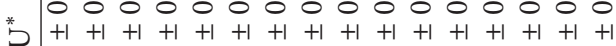

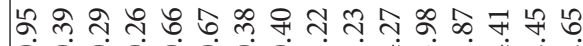

0. 0 o

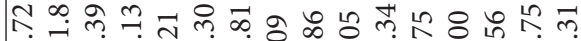

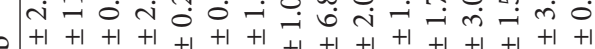

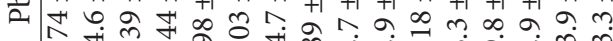

过

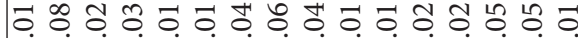

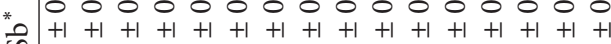

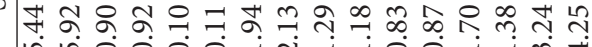

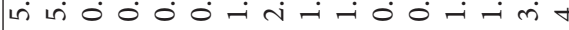

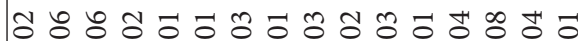

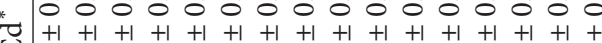

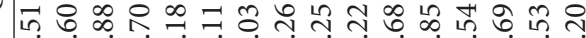

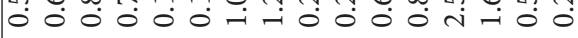

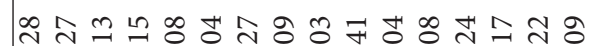

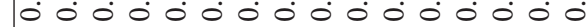

$27+1+1+1+1+1+1+1+1+1+1+1+1+1+1+1+1$

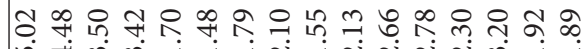

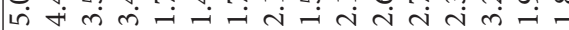

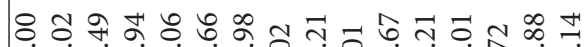
त :

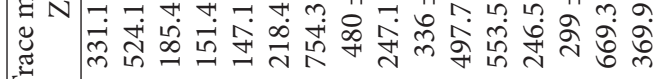

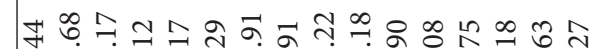

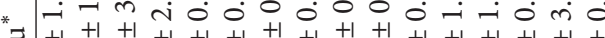

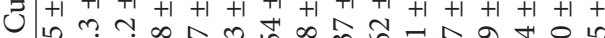
$\infty$ Iิ

แ i

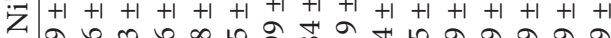

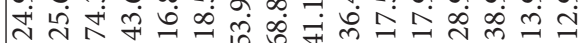

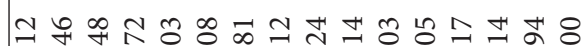
7 त. $0+1+1+1+1+1+1+1+1+1+1+1+1+1+1+1+1$

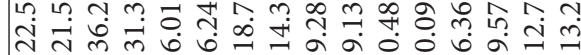

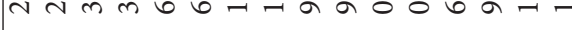

চ - -

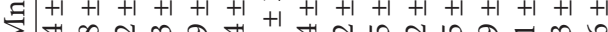

oं

$m$ in $n$ 윰ำ

-

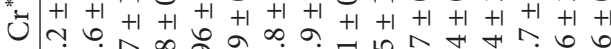

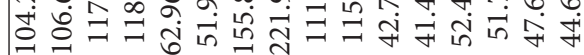

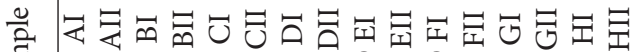

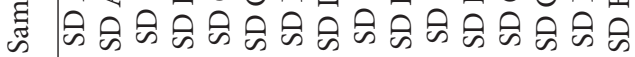

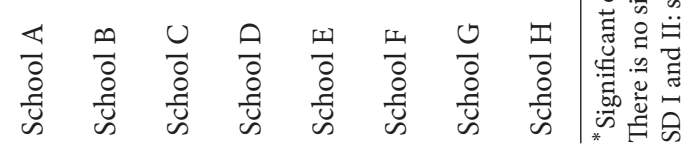


dust, which may decrease as proper cleaning increases [20]. It should be noted from the description of the school that there are no pavements and that some of the schools are close to a very busy road and cleaning of the classrooms is usually carried out once in a week; hence the metals might have accumulated in the classroom dust over time. The trend in trace metals concentrations from the present study is similar to those reported in Lagos, Nigeria [2]. The study revealed significantly high concentration of $\mathrm{Pb}$ from classroom dusts. A report pointed out from a separate study conducted in Nigeria that $\mathrm{Pb}$ from most classrooms in their study were well above the limit of $140 \mu \mathrm{g} / \mathrm{g}$ set by California Human Health Limits [21, 22]. Sources of $\mathrm{Pb}$ in the classrooms may be a result of the influence of the winds which can cause quantities of $\mathrm{Pb}$-bearing soil particles from the road sides to be deposited into the classrooms since the windows of the classrooms are usually opened and cleaning may not take place every school day [23]. Movements of the students around the $\mathrm{Pb}$ polluted soil may also increase the level of $\mathrm{Pb}$ in the classroom dust. However, it is important to note that $\mathrm{Pb}$ gets into human systems especially the young ones either through ingestion while playing on soil contaminated with $\mathrm{Pb}$ or through dermal contact [24]. A report from Nigeria showed that $\mathrm{Pb}$ poisoning may cause death as was in the case of 200 children who died as a result of $\mathrm{Pb}$ poisoning from $\mathrm{Pb}$ ore mining sites [24].

Chromium concentration from all the schools soil dust (SD) and classroom dust (CD) ranged from $41.4 \pm 0.75 \mu \mathrm{g} / \mathrm{g}$ to $221.9 \pm 2.65 \mu \mathrm{g} / \mathrm{g}$ and from $23.7 \pm 0.85 \mu \mathrm{g} / \mathrm{g}$ to $95.9 \pm 2.01 \mu \mathrm{g} / \mathrm{g}$, respectively (Tables 1 and 2). The Canadian Soil Quality Guidelines for Environmental Protection set the maximum limit for $\mathrm{Cr}$ in soil at $64 \mu \mathrm{g} / \mathrm{g}$; however, the background value in South Africa is around $250 \mu \mathrm{g} / \mathrm{g}$ [19]. Dermal exposure to chromium has been demonstrated to produce irritant and allergic contact, while there could also be a significant risk for respiratory cancer [25].

The mean concentrations for Mn ranged between $39.2 \pm$ $1.40 \mu \mathrm{g} / \mathrm{g}$ and $430.2 \pm 1.88 \mu \mathrm{g} / \mathrm{g}$. The highest mean concentration for $\mathrm{Mn}$ from the classroom dusts was recorded from School $\mathrm{H}$ with a mean value of $430.2 \pm 1.88 \mu \mathrm{g} / \mathrm{g}$ and was closely followed by School B with a value of $338.4 \pm 5.42 \mu \mathrm{g} / \mathrm{g}$. From the soil dust samples, the highest mean concentration for this metal was recorded from School B with a mean value of $412.2 \pm 0.13 \mu \mathrm{g} / \mathrm{g}$ followed by School D with a mean value of $392.4 \pm 1.06 \mu \mathrm{g} / \mathrm{g}$. The least mean concentration for $\mathrm{Mn}$ from all the dust samples was recorded from classroom dust from School E (Tables 1 and 2). There was a significant difference in the concentrations of $\mathrm{Mn}$ from all the schools $(p<0.05)$. Generally, schools that were close to very busy roads and that were not properly cleaned had the highest concentrations of $\mathrm{Mn}$ from their dust samples. Presence of $\mathrm{Mn}$ in the environment may be linked to manganese containing fuel additive methyl cyclopentadienyl manganese tricarboxylic (MMT) which was introduced in South Africa in 2005 when unleaded fuel was faced out as a replacement for organolead compound in petrol. Major sources of Mn determined from soil samples collected from different areas in Pretoria were mainly from the combustion of vehicular MMT [12]. Excessive intake of Mn through inhalation may accumulate in the brain which may sometimes lead to Parkinson's disease [26].

$\mathrm{Ni}, \mathrm{Cu}$, and $\mathrm{Co}$ concentrations were in the ranges of $10.58 \pm 0.22 \mu \mathrm{g} / \mathrm{g}-74.3 \pm 1.48 \mu \mathrm{g} / \mathrm{g}, 10.3 \pm 0.29 \mu \mathrm{g} / \mathrm{g}-157.2 \pm$ $3.17 \mu \mathrm{g} / \mathrm{g}$, and $0.02 \pm 0.00 \mu \mathrm{g} / \mathrm{g}-36.2 \pm 1.48 \mu \mathrm{g} / \mathrm{g}$, respectively. The standard reference value for NI in South Africa is $150 \mu \mathrm{g} / \mathrm{g}$. The highest mean concentrations for all these trace elements were recorded from School B and the values exceeded the background values recorded for South African soils [19]. The source of $\mathrm{Cu}$ and $\mathrm{Ni}$ could be from car components, tyre abrasion, engine wear, and brake dust, respectively [4]. The result of this study showed that the primary influence of these metals could be from vehicular activities which may be influenced by movement of learners around the area and eventually into the classrooms through the opening of windows. Nickel and certain nickel compounds have been listed by the National Toxicology Program (NTP) as being reasonably anticipated to be carcinogens [4].

Generally, from most of the schools where there were no grasses or lawns, the concentrations of trace metals from the dust samples were more than those recorded from schools that have pavement and well maintained lawns. The values for the concentrations of trace metals recorded from classroom dust collected from Schools H, B, and D were significantly higher than all other schools $(p<0.05)$. This may be due to the cleaning method employed in the school or closeness to a busy road.

During the course of sampling, a brief discussion with some of the educators revealed that regular cleaning of the classrooms may be an important factor in reducing the concentrations of trace metals in the classrooms. Schools where cleaning was carried out once in a week and done by learners were those that presented the highest mean level for all the trace metals. Accumulation of dust from different areas which is carried to classrooms by students might have increased the concentration of trace metals in the dust [16]. Vegetation and pavement also seem to have prevented the movement of the dust in some of the schools, thereby reducing the volume of trace metals in classrooms, or prevent direct exposure to wind erosion, thereby reducing the accumulations and the levels of trace metals in the dust collected from the playing ground. Ventilation and cleaning processes are the major contributing factors to the presence of heavy metals in classrooms from a school in Malaysia [27].

Pearson's positive correlations of $>0.5$ reported for trace metals such as $\mathrm{Pb}$ and $\mathrm{Zn}, \mathrm{Pb}$ and $\mathrm{Ni}, \mathrm{Pb}$ and $\mathrm{Sb}, \mathrm{Cu}$ and $\mathrm{Zn}$, and $\mathrm{Pb}$ and $\mathrm{Mn}$ from most of the schools suggested a common source for all the pollutants. The cluster analysis using principal component analysis as depicted in Figure 9 also showed a common source for some of the elements in some of the schools. From the present study, it was observed that most of the schools were just few meters away from busy roads and pollution from vehicular emission might have been the major source of these metals.

\section{Conclusion}

The present study investigated the levels of trace metals from selected schools in Pretoria, South Africa. The mean highest 


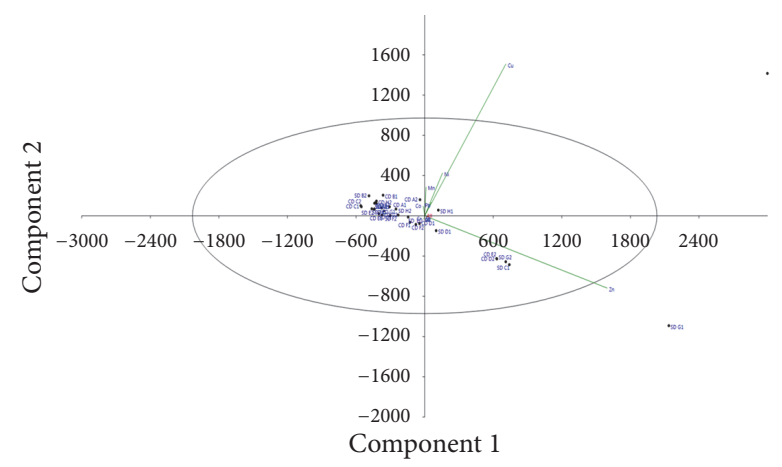

FIGURE 9: Cluster analysis showing the possible common source for most of the trace metals in some of the schools.

level of trace metals was recorded for most metals from Schools H, B, and D in this study. These schools according to the report from the educators showed that the cleaning of the classrooms is only carried out once in a week by the learners and windows are always open for proper ventilation. Since parents and taxis dropped off students at schools and because of the vehicular movements of cars around the area, it may be difficult to reduce the numbers of vehicles coming in and out of the schools; however, cleaning and ventilation not only seem to be more effective in reducing the volume of dust in classrooms but also may assist in preventing the accumulation of trace metals in classrooms dust, thereby reducing the level of trace metals from dust collected from the classrooms. Planted grasses, well maintained lawn, and pavement also seem to have prevented the movement of the dust in some of the schools and this should be encouraged. Closeness to busy roads may bring about not only noise pollution as pointed out by the educators but also a potential source of trace metals as demonstrated from our study. Elevated concentrations for $\mathrm{Pb}, \mathrm{Mn}, \mathrm{Cu}, \mathrm{Zn}$, and $\mathrm{Cr}$ reported in this study may be a source of concern. Children attending some of the schools, especially schools without proper cleaning carried out in the classrooms, may be prone to trace metal related diseases.

\section{Competing Interests}

The authors declare that there are no competing interests.

\section{Acknowledgments}

The authors are grateful to Gauteng Department of Education for granting the approval to conduct this study, the principals, staff, and students of the schools where samples were collected, and the Department of Biology staff members under the headship of Professor P. King for their meaningful contribution during the presentation of the research work. The assistance provided by Mr. Olawole Aina is also gratefully appreciated.

\section{References}

[1] H. Saeedi, A. A. Ardalan, B. Kiabi, and R. Zibaseresht, "Metal concentrations in razor clam Solen dactylus (Von Cosel, 1989)
(Bivalvia: Solenidae), sediments and water in Golshahr coast of Bandar Abbas, Persian Gulf," Iranian Journal of Fisheries Science, vol. 11, pp. 165-183, 2012.

[2] O. E. Popoola, O. Bamgbose, O. J. Okonkwo, T. A. Arowolo, O. A. Popoola, and O. R. Awofolu, "Heavy metals content in classroom dust of some public primary schools in metropolitan Lagos, Nigeria," Research Journal of Environmental and Earth Sciences, vol. 4, pp. 460-465, 2012.

[3] O. J. Okunola, A. Uzairu, and G. Ndukwe, "Levels of trace metals in soil and vegetation along major and minor roads in metropolitan city of Kaduna, Nigeria," African Journal of Biotechnology, vol. 6, no. 14, pp. 1703-1709, 2007.

[4] F. M. Darus, R. A. Nasir, S. M. Sumari, Z. S. Ismail, and N. A. Omar, "Heavy metals composition of indoor dust in nursery schools building, Malaysia," Social and Behavioral Sciences, vol. 38, pp. 169-175, 2012.

[5] Z. Li, Z. Z. Ma, T. Jan van der Kuijp, Z. Yuan, and L. Huang, "A review of soil heavy metal pollution from mines in China: pollution and health risk assessment," Science of the Total Environment, vol. 468-469, pp. 843-853, 2014.

[6] G. T. Shi, Z. L. Chen, C. J. Bi et al., "A comparative study of health risk of potentially toxic metals in urban and suburban road dust in the most populated city of China," Atmospheric Environment, vol. 45, no. 3, pp. 764-771, 2011.

[7] P. Gao, S. Liu, W. Ye et al., "Assessment on the occupational exposure of urban public bus drivers to bioaccessible trace metals through resuspended fraction of settled bus dust," Science of the Total Environment, vol. 508, pp. 37-45, 2015.

[8] A. Y. Y. Kong, K. M. Scow, A. L. Córdova-Kreylos, W. E. Holmes, and J. Six, "Microbial community composition and carbon cycling within soil microenvironments of conventional, low-input, and organic cropping systems," Soil Biology and Biochemistry, vol. 43, no. 1, pp. 20-30, 2011.

[9] S. Mass, R. Scheifler, M. Benslama et al., "Spatial distribution of heavy metals concentrations in urban, suburban and agricultural soils in Mediterranean city of Algeria," Environmental Pollution, vol. 152, pp. 73-81, 2010.

[10] N. M. Tahir, P. S. Chee, and M. Jaafar, "Determination of heavy metals content in soils and indoor dusts from nurseries in Dungun, Terengganu Malaysian," Journal of Analytical Sciences, vol. 11, pp. 280-286, 2007.

[11] F. A. Adekola and O. O. Dosumu, "Heavy metal determination in household dusts from Ilorin city, Nigeria," NISEB Journal, vol. 1, no. 3, pp. 217-221, 2001.

[12] T. J. N. Okonkwo, O. Okorie, and C. J. O. Okonkwo, "Public health risk status of the water supply frame work at Kwame Nkrumah (Postgraduate) Hall, University of Nigeria, Nsukka and environment," African Journal of Environmental Science and Technology, vol. 5, pp. 522-529, 2011.

[13] J. O. Olowoyo, O. O. Okedeyi, N. M. Mkolo, G. N. Lion, and S. T. R. Mdakane, "Uptake and translocation of heavy metals by medicinal plants growing around a waste dump site in Pretoria, South Africa," South African Journal of Botany, vol. 78, pp. 116121, 2012.

[14] T. Kootbodien, A. Mathee, N. Naicker, and N. Moodley, "Heavy metal contamination in a school vegetable garden in Johannesburg," South African Medical Journal, vol. 102, no. 4, pp. 226-227, 2012.

[15] G. L. Liggans and J. O. Nriagu, "Lead poisoning of children in Africa, IV: exposure to dust lead in primary schools in south-central Durban, South Africa," The Science of the Total Environment, vol. 221, no. 2-3, pp. 117-126, 1998. 
[16] J. O. Olowoyo, L. L. Mugivhisa, and S. C. Sithole, "Exposure to trace metals from dust samples collected from air conditioning systems and carpets from offices in a university," Trace Elements and Electrolytes, vol. 32, no. 4, pp. 225-232, 2015.

[17] F. Amato, X. Querol, A. Alastuey et al., "Evaluating urban $\mathrm{PM}_{10}$ pollution benefit induced by street cleaning activities," Atmospheric Environment, vol. 43, no. 29, pp. 4472-4480, 2009.

[18] H. G. Snyman and J. E. Herselman, "Requirements for the agricultural use of wastewater sludge," Guidelines for the Utilisation and Disposal of Wastewater Sludge, vol. 2, Article ID TT262, 6 pages, 2006.

[19] M. W. Xaba and J. O. Olowoyo, Preliminary investigation on the impact of heavy metals emission on soil and vegetation around a coal-fired power station [M.S. thesis], Department of Biology, Sefako Makgatho Health Sciences University, Pretoria, South Africa, 2016.

[20] B. Chattopadhyay, A. Chatterjee, and S. K. Mukhopadhyay, "Bioaccumulation of metals in the East Calcutta wetland ecosystem," Aquatic Ecosystem Health and Management, vol. 5, no. 2, pp. 191-203, 2002.

[21] O. O. Olujimi, O. Ogheneochuko, O. Fatoki, E. O. Oluwabamise, O. A. Aroyewun, and J. Baruani, "Heavy metals speciation and human health risk assessment at an illegal gold mining site in igun, Osun State, Nigeria," Journal of Health and Pollution, vol. 5, no. 8, pp. 19-32, 2015.

[22] United State Environmental Protection Agency, Integrated Risk Information System (IRIS), National Center for Environmental Assessment, Office of Research and Development, Washington, DC, USA, 2001.

[23] P. C. Onianwa, "Environmental pollution studies in an underdeveloped country (I): heavy metal pollution in Ibadan, Nigeria," International Journal of Environmental Education and Information, vol. 12, pp. 25-34, 1993.

[24] B. A. Adelekan and K. D. Abegunde, "Heavy metals contamination of soil and groundwater at automobile mechanic villages in Ibadan, Nigeria," International Journal of Physical Sciences, vol. 6, no. 5, pp. 1045-1058, 2011.

[25] United State Environmental Protection Agency, "Soil screening guidance: technical background document," Tech. Rep. EPA/540/R-95/128, Office of Solid Waste and Emergency Response, Washington, DC, USA, 1996.

[26] D. Mergler, G. Huel, R. Bowler et al., "Nervous system dysfunction among workers with long-term exposure to Manganese," Environmental Research, vol. 64, no. 2, pp. 151-180, 1994.

[27] S. M. Praveena, B. Pradhan, and S. N. S. Ismail, "Spatial assessment of heavy metals in surface soil from Klang district (Malaysia): an example from a tropical environment," Human and Ecological Risk Assessment, vol. 21, no. 7, pp. 1980-2003, 2015. 

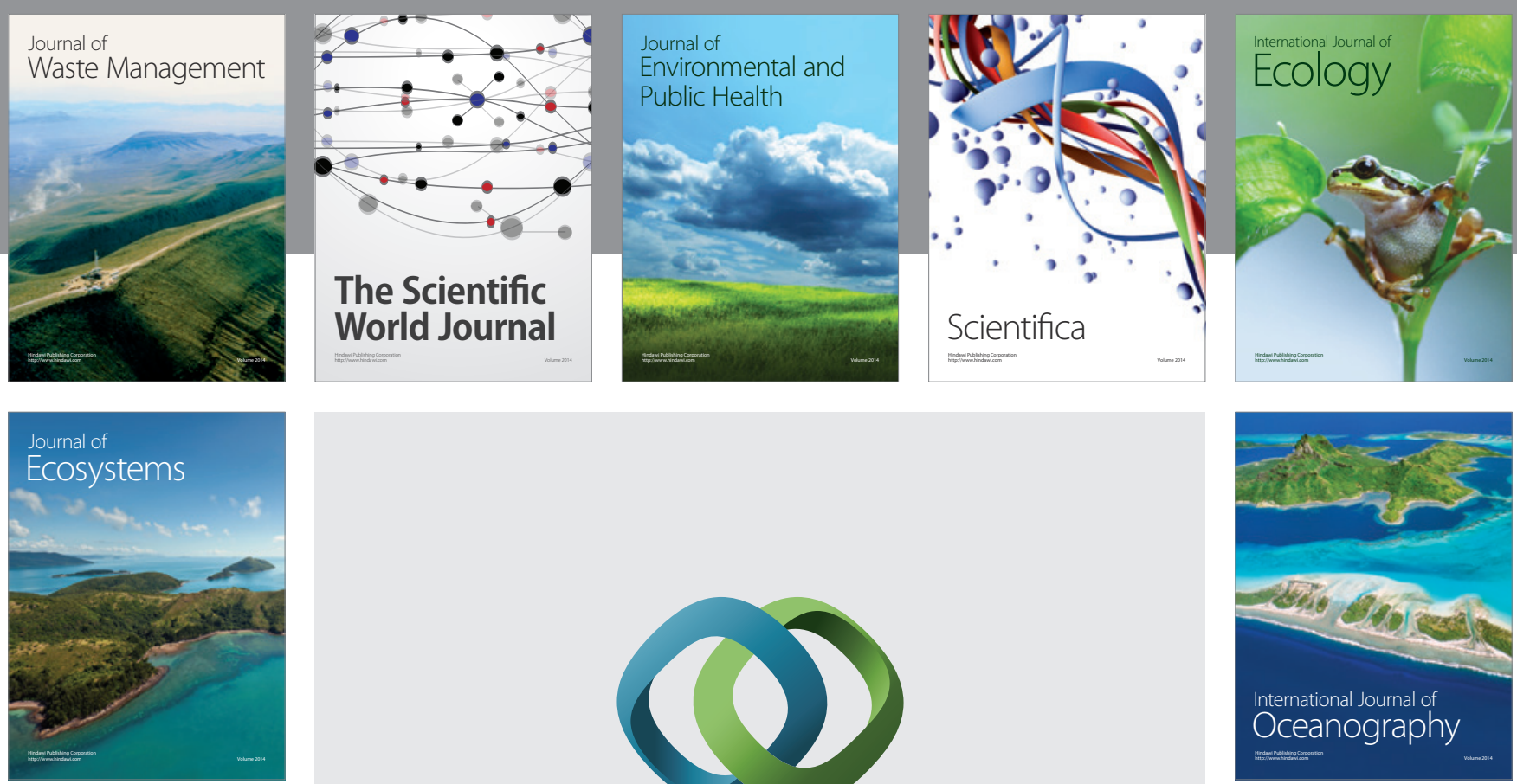

The Scientific World Journal
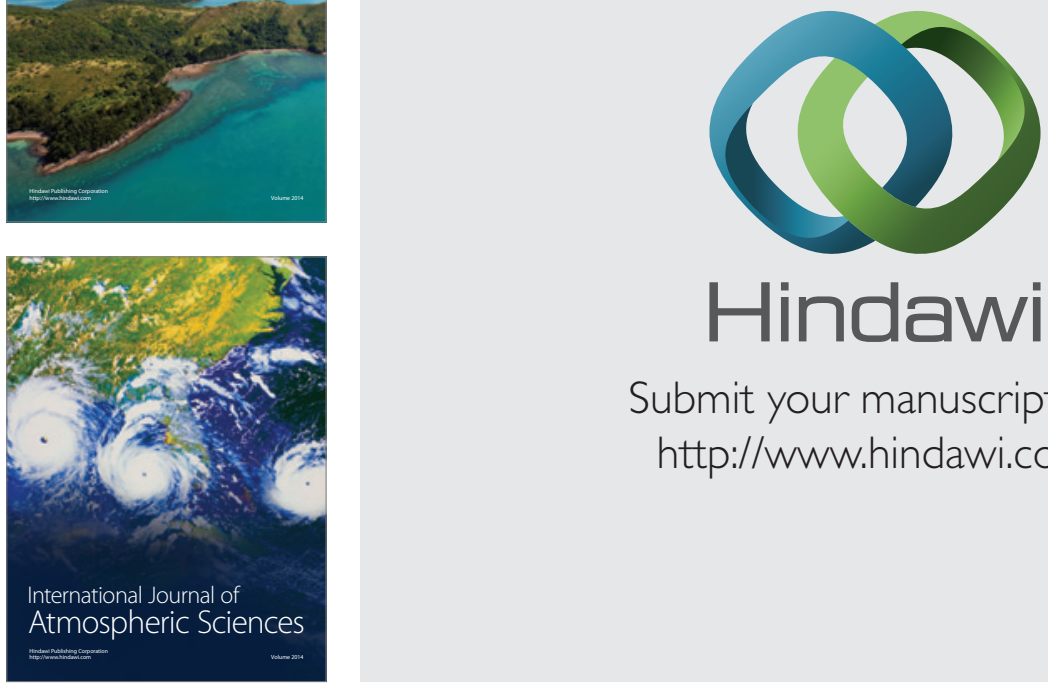

\section{Hindawi}

Submit your manuscripts at

http://www.hindawi.com
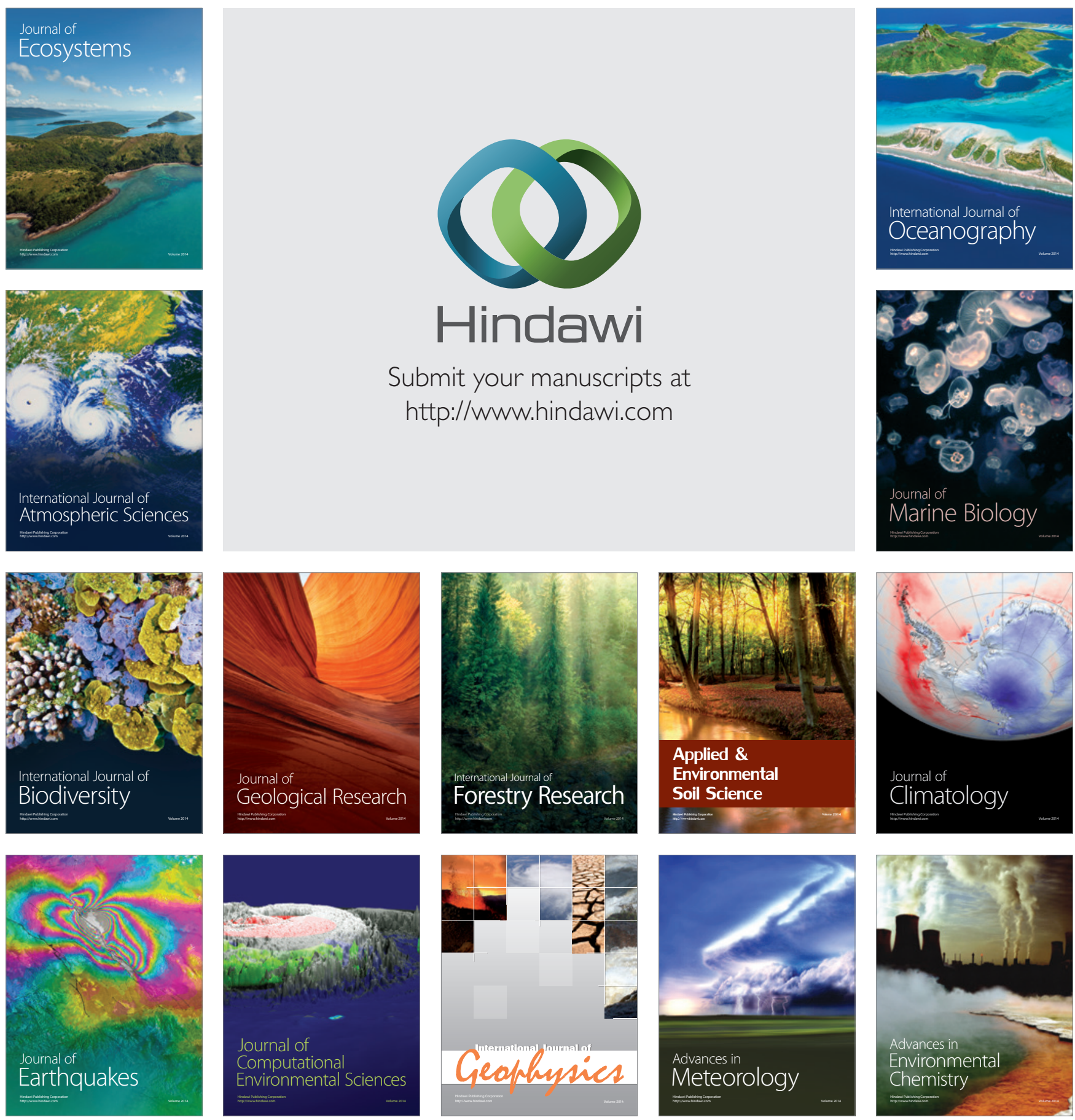